\title{
Nanocomposites films obtained from protein isolates of mechanically deboned chicken meat added with montmorillonite
}

\author{
Bruna da Silva Menezes ${ }^{1}$, William Renzo Cortez-Vega ${ }^{2 *}$ and Carlos Prentice ${ }^{1}$ \\ 'Laboratory of Food Technology, School of Chemistry and Food, Universidade Federal do Rio Grande, \\ Rio Grande, $R S$, Brazil \\ ${ }^{2}$ Laboratory of Bioengineering, Faculty of Engineering, Universidade Federal da Grande Dourados, \\ Dourados, MS, Brazil \\ *carlos.prentice@gmail.com
}

\begin{abstract}
The aim of this study was to evaluate the properties of nanocomposite films of protein isolates from mechanically deboned chicken meat with organoclay (montmorillonite). For the film development, a $2^{3}$ experimental design was performed with three levels, protein isolate $\left(2,3.5,5 \mathrm{~g} .100 \mathrm{~mL}^{-1}\right.$ of solution), montmorillonite $\left(0.3,0.5,0.7 \mathrm{~g} .100 \mathrm{~mL}^{-1}\right.$ of solution) and glycerol $\left(25,30,35 \mathrm{~g} .100 \mathrm{~mL}^{-1} \mathrm{CPI}\right)$. The tensile strength varied between 6.7 and 9.1 MPa, elongation to break from $26-66 \%$, opacity of 13.1 to 35.7 and solubility from $38.5 \%$ to $81.8 \%$. Assessing the structural properties, interleaving of the isolate and montmorillonite can be noted. The results obtained in the experimental design indicate that $2.0 \mathrm{~g}$ of CPI. $100 \mathrm{~g}^{-1}$ of solution, $0.8 \mathrm{~g}$ of MMT. $100 \mathrm{~g}^{-1}$ of solution and $0.2 \mathrm{~g}$ of glicerol. $100 \mathrm{~g}^{-1} \mathrm{CPI}$ are the ideal parameters for preparing nanocomposite films.
\end{abstract}

Keywords: by-product, chicken, protein isolate, film.

\section{Introduction}

Concentrated and isolated proteins are produced in large scale to serve as functional ingredients in a wide and increasing range of food applications. When replacing conventional proteins, protein concentrates and isolates maintain or improve the quality and acceptability of the products that have been incorporated ${ }^{[1]}$.

The interest of maintaining or improving the quality of packaged goods and reducing the waste of packaging at the same time has encouraged the exploration of new packaging materials such as biodegradable films formulated with raw materials derived from renewable resources ${ }^{[2]}$.

Among the studied raw materials, natural biopolymers, such as polysaccharides and proteins appear most promising for developing films, because they are abundant, renewable, cheap and capable of forming a continuous matrix ${ }^{[3]}$.

The choice of material for use in the formulation of films and coatings is very important, as this will depend on the interactions between the components of the material, which may interfere with barrier, mechanical and sensory properties of films ${ }^{[4]}$.

This association between biopolymers and nanoparticles aims to obtain synergistic effects, it is one of the most innovative ways to enhance the properties of these matrices. Depending on the geometry and nature of the nanoparticle, new properties such as gas barrier, mechanical strength, transparency and thermal stability are improved ${ }^{[5]}$.

In this field, special attention has been given to montmorillonite (MMT) because of its small particles, extremely large surface area and good interleaving properties. Montmorillonite is composed of silicate layers with a thickness of approximately $1 \mathrm{~nm}$ in the planar structure, and a lateral dimension between 200 and $300 \mathrm{~nm}$. Its typical chemical structure consists of two tetrahedral silica layers surrounding a layer of octahedral aluminum hydroxide or magnesium ${ }^{[6]}$.

With the addition of between 2 and $10 \%$ of montmorillonite clay, nanocomposites can introduce significant improvements in their mechanical, optical and barrier properties. This advantage of adding low clay content, compared to the traditional composites, means the production of lighter components, a desirable factor in many applications. Another interesting properties usually presented by polymer/clay nanocomposites is higher microbial stability ${ }^{[7]}$.

The main reason for the differences in performance between composite and nanocomposite materials is related to the high surface area of the latter, resulting in high interaction between the matrix and the nanoparticles ${ }^{[8]}$.

Thus, the aim of this study is to take advantage of a by-product from the chicken processing industry for the production of chicken protein isolate films and evaluate their properties by varying the concentration of the protein isolate, the plasticizer, and montmorillonite clay.

\section{Materials and Methods}

\subsection{Development of films}

For the development of active protein isolate films from mechanically deboned chicken meat (MDCM), a $2^{3}$ experimental design was carried out, with three central points and axial points. Response surface methodology was applied to study the simultaneous effects of the independent variables 
(concentration of MDCM protein isolate $(\mathrm{CPI}=2,3.5$ and $5 \mathrm{~g}$ ); montmorillonite concentration $(\mathrm{MMT}=0.3,0.5$ and $0.7 \mathrm{~g})$ and glycerol plasticizer $(\mathrm{G}=25,30$ and $35 \% / \mathrm{g} \mathrm{CPI})$ on the tensile strength $(\mathrm{MPa})$, elongation to break $(\%)$, water vapor permeability (WVP), solubility and opacity responses.

The films were developed by the casting technique, where each solution of the film was prepared according to the experimental design data shown in Table 1.

\subsection{Thickness}

After the packaging period, the thickness of the films was obtained using a digital micrometer (INSIZE, IP 54) Resolution $0.0100 \pm 0.0005 \mathrm{~mm}$. The thickness was determined as the arithmetic mean of five random measurements of the area of the film.

\subsection{Mechanical properties}

The testing of tensile strength (TS) and elongation to break (E) was performed according to the standard method of the American Society for Testing and Materials, ASTM D-882 ${ }^{[9]}$. A section of the film with a width of $2.5 \mathrm{~cm}$ and a length of $9 \mathrm{~cm}$ was inserted into a texturometer (Stable Micro System, TA.XT plus) and subjected to a stretching force until the film ruptured. The tensile strength was expressed in $\mathrm{MPa}$ and elongation to break in $\%$.

\subsection{Water vapor Permeability (WVP)}

Water vapor permeability (WVP) assays were done gravimetrically at $25^{\circ} \mathrm{C}$ according to the E96-95 method ${ }^{[10]}$. The films were coupled with $\mathrm{CaCl}$ solution, previously dried at $105{ }^{\circ} \mathrm{C}$ for $2 \mathrm{~h}$, and stored in a desiccator with a relative humidity of $75 \%$ for 8 days, being weighed every 24 hours. The WVP calculation was performed according to Equation 1.

$$
\mathrm{P}=\frac{\mathrm{M}}{\mathrm{t}} \frac{\mathrm{L}}{\mathrm{A} \cdot \Delta \mathrm{P}}
$$

where $\mathrm{M}$ is the mass of absorbed moisture $(\mathrm{g})$; $\mathrm{t}$ is time in days; $\mathrm{L}$ is the thickness in $\mathrm{mm}$; $\mathrm{A}$ is the area in $\mathrm{m}^{2}$ and $\Delta \mathrm{P}$ is moisture variation on in $\mathrm{KPa}$.

\subsection{Solubility}

Water solubility of the films was determined in triplicate by the Fakhouri et al. ${ }^{[1]]}$ method. The films were cut into squares of $2 \mathrm{~cm}$, and the initial percentage of dry matter of the sample was determined in an oven (A1-SED, De Leo) at $105^{\circ} \mathrm{C}$ for 24 hours. After weighing, the samples were immersed in containers with $25 \mathrm{~mL}$ of distilled water, and stirred slowly in an orbital shaker (TE-420, Tecnal) for

Table 1. Variables used in the experimental design to develop active films

\begin{tabular}{cccccc}
\hline Real variables & \multicolumn{5}{c}{ Coded variables } \\
\hline & -1.68 & -1 & 0 & 1 & 1.68 \\
CPI $(\mathrm{g}) *$ & 1.0 & 2.0 & 3.5 & 5.0 & 6.0 \\
Glycerol $(\mathrm{g}) *$ & 0.2 & 0.5 & 1.0 & 1.5 & 1.8 \\
MMT $(\mathrm{g})^{*}$ & 0.2 & 0.3 & 0.5 & 0.7 & 0.8 \\
\hline
\end{tabular}

*CPI: Chicken protein isolate of MDCM; MMT: Montmorillonite.
24 hours. After this period, samples were removed and dried $\left(105^{\circ} \mathrm{C}\right.$ for 24 hours) to determine the mass of dry matter not dissolved in water.

\subsection{Opacity}

The opacity of the films was obtained using a visible UV spectrophotometer (Biospectro, SP-22) and calculated by the formula:

$$
\text { opacity }=\frac{\mathrm{A}_{450}}{\mathrm{X}}
$$

where $\mathrm{A}_{450}$ is the absorbance at $450 \mathrm{~nm}$, given by the equation $\mathrm{A}_{450}=-\log \mathrm{T}$ and $\mathrm{X}$ is film thickness $(\mathrm{mm})$.

\subsection{Scanning electron microscopy (SEM)}

Sample films were analyzed to determine the surface characteristics using a scanning electron microscope (JSM 6060, JEOL, Japan) operating at 15kV. Five samples were mounted in a brass tube and coated with a gold layer before obtaining the images. The photographs were taken at 10000x magnification. This analysis was performed at the Center of Electron Microscopy of South Zone (CEME-SUL) at the Federal University of Rio Grande.

\subsection{X-ray diffraction (XRD)}

The analysis of X-ray diffraction (XRD) were obtained using a diffractometer (Siemens D500 of Bragg-Brentanogeometry) with $\mathrm{Cu}$ radiation, operating at $40 \mathrm{kV}$ and $17.5 \mathrm{~mA}$, graphite monochromator for diffracted $\mathrm{X}$-ray beams. The measurements were obtained in steps of 0.05 degrees $(2 \theta)$, counting time of 5 seconds/step and measurement intervals in $2 \Theta$ from 2 to 60 degrees. The analysis was performed at the Electron Microscopy Center (CME) of the Federal University of Rio Grande do Sul - UFRGS.

\subsection{Infrared spectroscopy (FTIR)}

The films were analyzed according to Attenuated Reflectance FTIR-ATR method; using spectrophotometric equipment on infrared (Prestige, 210,045-Japan) with 40 scans in the Laboratory of Synthesis and Inorganic Catalysis in the Federal University of Rio Grande.

\subsection{Statistical analysis}

To statistically determine significant differences with $95 \%$ confidence between means $(\mathrm{p}=0.05)$, analysis of variance and Tukey's test were used and for the development of the films a response surface methodology was applied to study the simultaneous effects of the variables independent on responses on Statistica 7.0 software (Statsoft, USA).

\section{Results and Discussion}

\subsection{Film properties}

\subsubsection{Physical thickness}

Table 2 shows the thickness values obtained, with the amount of filmogenic solution placed on the plate and thickness. 
The thickness was determined as the arithmetic average of five random measurements of the area of the film, it was found that with an increase in solids, thickness increased too, same behavior found by Brandelero et al. ${ }^{[12]}$ who determined thicknesses of starch films in the same way and obtained a variation in thickness from $0.11 \mathrm{~mm}$ to $0.33 \mathrm{~mm}$. On the other hand, Cortez-Vega et al. ${ }^{[13]}$ also determined the film thickness of croaker protein isolate by the mean of 10 thickness measurements. Therefore, the value of the average thickness $(0.2 \mathrm{~mm})$ was maintained for the planning, according to the amount of solution placed in the plate $(15.5 \mathrm{~g})$, since these values showed better tensile strength and elongation to break characteristics from preliminary tests.

\subsubsection{Physicochemical properties}

Responses surfaces were obtained to evaluate the effect of independent variables, chicken protein isolate (CPI), montmorillonite (MMT) and glycerol (G) on the dependent variables (tensile strength, elongation, opacity, solubility and water vapor permeability).

Table 3 shows the matrix of the experimental design and the results obtained for the assays. The central points for the answers showed little variation, indicating a good repetitiveness of the process.

Table 2. Determination of the thickness of chicken isolate and nanoclay films.

\begin{tabular}{ccc}
\hline & $\begin{array}{c}\text { Amount of filmogenic } \\
\text { solution }(\mathbf{g})\end{array}$ & $\begin{array}{c}\text { Thickness } \\
(\mathbf{m m})\end{array}$ \\
\hline \multirow{4}{*}{ Mean } & 14.5 & $0.18 \pm 0.11$ \\
& 15.0 & $0.19 \pm 0.07$ \\
& 15.5 & $0.20 \pm 0.10$ \\
& 16.0 & $0.21 \pm 0.08$ \\
17.0 & $0.22 \pm 0.12$ \\
\hline
\end{tabular}

Table 3 shows the experimental design matrix and results obtained for the dependent variables tensile strength, elongation, opacity, solubility and water vapor permeability (WVP). However, only the tensile strength, opacity and solubility were influenced by the process variables.

For the variables elongation to break and water vapor permeability (WVP), $\mathrm{F}_{\text {calculated }}$ was less than $\mathrm{F}_{\text {tabulated }}$, thus the model was not predictive, not being possible to generate the response surface ${ }^{[14]}$. Therefore, the elongation to break and WVP were not influenced by the process variables.

According to the process conditions, the tensile strength of the films of chicken protein isolate with montmorillonite ranged from 6.7 to $9.1 \mathrm{MPa}$ and elongation to break of $26-66 \%$. On the other hand, Zavareze et al. ${ }^{[15]}$ found tensile strength ranging from 4.0 to $5.7 \mathrm{MPa}$ and elongation to break of $102-193 \%$ in myofibrillar fish protein films, in croaker protein isolate films with the addition of montmorillonite found TS from 7.2 to $10.7 \mathrm{MPa}$ and elongation to break from 39.6 to $45.8 \%{ }^{[13]}$.It can be seen then that the films obtained in this work showed reasonable resistance compared to other films derived from meat protein isolates, possibly due to the addition of montmorillonite, obtaining values close to those of Cortez-Vega et al. ${ }^{[13]}$ who also used nanoclay. As for the elongation, variability greater than that of other authors was obtained. Elongation to break depends principally on the plasticizer values, and increasing the concentration of glycerol and sorbitol improves the elongation to break of films ${ }^{[16]}$.

Therefore, one can view the tensile strength conditions as a function of the protein isolate concentrations, montmorillonite and glycerol in Figure 1a and 1b, and conclude that the tensile strength becomes higher with maximum $(0.8 \mathrm{~g})$ and minimum amounts $(0.2 \mathrm{~g})$ of MMT and less glycerol, regardless of the amount of protein isolate.

According to the process conditions, the opacity ranged from 13.1 to 35.7 and the solubility from $38.5 \%$ to $81.8 \%{ }^{[17]}$,

Table 3. Results and experimental design matrix used to evaluate the mechanical properties of chicken protein isolate and nanoclay films.

\begin{tabular}{|c|c|c|c|c|c|c|c|c|}
\hline Assay & $\begin{array}{c}\text { CPI } \\
(\mathrm{g} / 100 \mathrm{~mL})\end{array}$ & $\underset{(\mathrm{g} / 100 \mathrm{~mL})}{\mathrm{MMT}}$ & $\begin{array}{l}\text { Glycerol } \\
\text { (g/100mL) }\end{array}$ & $\begin{array}{c}\text { Tensile } \\
\text { Strength* } \\
\text { (MPa) }\end{array}$ & $\begin{array}{c}\text { Elongation to } \\
\text { break* }(\%)\end{array}$ & Opacity* & $\begin{array}{l}\text { Solubility* } \\
\text { (\%) }\end{array}$ & $\begin{array}{c}\text { WVP* } \\
(\text { g.mm/m².d.kPa) }\end{array}$ \\
\hline 1 & $-1(2.0)$ & $-1(0.3)$ & $-1(0.5)$ & $8.6 \pm 0.11$ & $41 \pm 0.06$ & $13.7 \pm 0.32$ & $46.5 \pm 0.74$ & $1.74 \pm 0.68$ \\
\hline 2 & $+1(5.0)$ & $-1(0.3)$ & $-1(0.5)$ & $8.6 \pm 0.15$ & $44 \pm 0.11$ & $18.6 \pm 0.53$ & $39.7 \pm 0.60$ & $1.23 \pm 0.18$ \\
\hline 3 & $-1(2.0)$ & $-1(0.3)$ & $+1(1.5)$ & $7.6 \pm 0.20$ & $26 \pm 0.16$ & $13.1 \pm 0.52$ & $53.1 \pm 0.54$ & $1.21 \pm 0.01$ \\
\hline 4 & $+1(5.0)$ & $-1(0.3)$ & $+1(1.5)$ & $7.6 \pm 0.13$ & $29 \pm 0.13$ & $16.0 \pm 0.18$ & $53.6 \pm 0.25$ & $1.30 \pm 0.15$ \\
\hline 5 & $-1(2.0)$ & $+1(0.7)$ & $-1(0.5)$ & $7.5 \pm 0.18$ & $36 \pm 0.17$ & $14.8 \pm 0.82$ & $38.5 \pm 0.09$ & $1.23 \pm 0.40$ \\
\hline 6 & $+1(5.0)$ & $+1(0.7)$ & $-1(0.5)$ & $6.7 \pm 0.23$ & $66 \pm 0.22$ & $35.7 \pm 0.07$ & $71.8 \pm 0.34$ & $1.64 \pm 0.01$ \\
\hline 7 & $-1(2.0)$ & $+1(0.7)$ & $+1(1.5)$ & $6.8 \pm 0.26$ & $28 \pm 0.04$ & $15.3 \pm 1.06$ & $48.4 \pm 0.05$ & $2.83 \pm 0.11$ \\
\hline 8 & $+1(5.0)$ & $+1(0.7)$ & $+1(1.5)$ & $8.4 \pm 0.11$ & $36 \pm 0.12$ & $16.5 \pm 0.49$ & $54.0 \pm 0.24$ & $1.04 \pm 0.25$ \\
\hline 9 & $-1.68(1.0)$ & $0(0.5)$ & $0(1.0)$ & $8.4 \pm 0.22$ & $44 \pm 0.05$ & $15.2 \pm 0.50$ & $81.8 \pm 0.78$ & $2.01 \pm 0.31$ \\
\hline 10 & $+1.68(6.0)$ & $0(0.5)$ & $0(1.0)$ & $7.4 \pm 0.24$ & $46 \pm 0.13$ & $20.0 \pm 0.36$ & $46.5 \pm 0.09$ & $1.51 \pm 0.09$ \\
\hline 11 & $0(3.5)$ & $0(0.5)$ & $-1.68(0.2)$ & $7.9 \pm 0.19$ & $56 \pm 0.16$ & $17.6 \pm 0.83$ & $38.6 \pm 0.13$ & $1.33 \pm 0.09$ \\
\hline 12 & $0(3.5)$ & $0(0.5)$ & $+1.68(1.8)$ & $7.0 \pm 0.13$ & $35 \pm 0.26$ & $14.7 \pm 0.41$ & $43.6 \pm 0.22$ & $1.74 \pm 0.44$ \\
\hline 13 & $0(3.5)$ & $-1.68(0.2)$ & $0(1.0)$ & $9.1 \pm 0.12$ & $52 \pm 0.11$ & $13.5 \pm 0.59$ & $42.2 \pm 0.20$ & $1.00 \pm 0.01$ \\
\hline 14 & $0(3.5)$ & $+1.68(0.8)$ & $0(1.0)$ & $8.9 \pm 0.11$ & $40 \pm 0.10$ & $17.8 \pm 0.89$ & $40.7 \pm 1.10$ & $1.76 \pm 0.33$ \\
\hline 15 & $0(3.5)$ & $0(0.5)$ & $0(1.0)$ & $7.8 \pm 0.22$ & $39 \pm 0.05$ & $14.7 \pm 0.59$ & $40.9 \pm 0.37$ & $1.09 \pm 0.03$ \\
\hline 16 & $0(3.5)$ & $0(0.5)$ & $0(1.0)$ & $8.0 \pm 0.02$ & $39 \pm 0.01$ & $16.5 \pm 0.29$ & $45.7 \pm 0.06$ & $1.08 \pm 0.01$ \\
\hline 17 & $0(3.5)$ & $0(0.5)$ & $0(1.0)$ & $8.0 \pm 0.09$ & $39 \pm 0.07$ & $16.0 \pm 0.33$ & $45.8 \pm 0.26$ & $1.07 \pm 0.03$ \\
\hline
\end{tabular}

*Mean values of 3 repetitions expressed as mean \pm standard deviation; CPI: Chicken protein isolate; MMT: Montmorillonite; WVP: water vapor Permeability. 
in chitosan films added with clay, found opacity from 14.0 to 31.9 , results within the range of values found in this study. In croaker protein isolate films with the addition of montmorillonite found opacity ranging from 12 to 13.5 and a solubility ranging from $18.1 \%$ to $27.6 \%{ }^{[13]}$. Thus it can be concluded that the films of this study showed higher opacity and solubility and greater variability from the other studies. State that it is important that the films exhibit low opacity, i.e, greater transparency for viewing the packaged product and also stating that it is best for films to have a lower solubility to protect the food and ensure quality during storage ${ }^{[15]}$.

From Figures $2 a$ and $2 b$, one can see the response surfaces of the opacity against chicken protein isolate concentrations, glycerol and montmorillonite.

It was possible to visualize the opacity conditions as a function of the concentrations of protein isolate, montmorillonite and glycerol in Figures $2 a$ and $2 b$, concluding that the opacity (13.7) decreases with a greater amount of MMT $(0.8 \mathrm{~g})$, least amount of glycerol $(0.2 \mathrm{~g})$, and higher values of protein isolate $(6 \mathrm{~g})$. This behavior is different to that found by Nascimento et al., because according to the author, increase in opacity occurs with increasing clay ${ }^{[17]}$.
In this case, this may be due to dilution of montmorillonite along with the other components of the film.

In Figures $3 a$ and $3 b$ the response surfaces of the solubility against the concentrations of chicken protein isolate, glycerol and montmorillonite.

It was possible to visualize the solubility conditions as a function of the concentration of protein isolate, montmorillonite and glycerol in Figure $3 \mathrm{a}$ and $3 \mathrm{~b}$, concluding that the solubility (13.7\%) decreases with greater amounts of MMT $(0.8 \mathrm{~g})$ and smaller amount of protein isolate $(1 \mathrm{~g})$, and is independent of the amount of glycerol. This behavior was similar to that showed by Nascimento et al. ${ }^{[17]}$, where the solubility was lower when the chitosan concentrations were lower and with the addition of clay.

From the response surface, the best formulation for the preparation of the films was chosen for further analysis. Interpreting the results of the response surface, the films with better properties were those with a maximum quantity of MMT $(0.8 \mathrm{~g} / 100 \mathrm{~mL})$, smaller amount of glycerol $(2 \mathrm{~g} / 100 \mathrm{~mL})$, since their quantity did not significantly influence the properties and intermediate quantity of the isolate $(2 \mathrm{~g} / 100 \mathrm{~mL})$ so as not to make the film opaque. a)

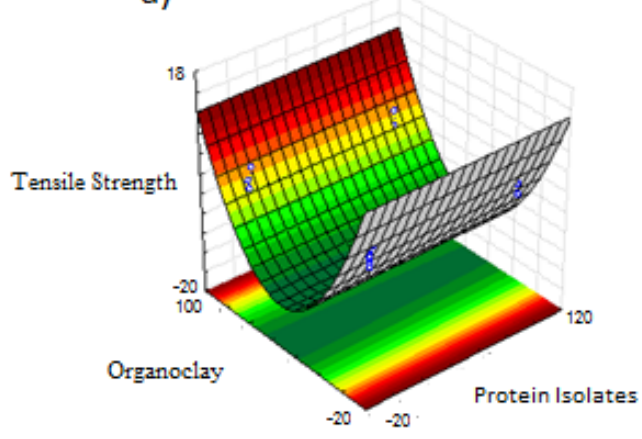

b)

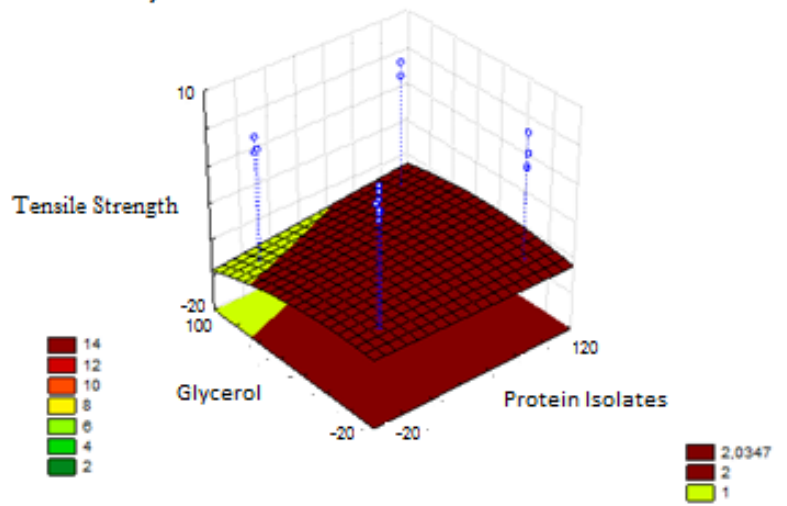

Figure 1. Response surface of tensile strength as a function of the concentration of (a) protein isolate and MMT (b) protein isolate and glycerol.

a)

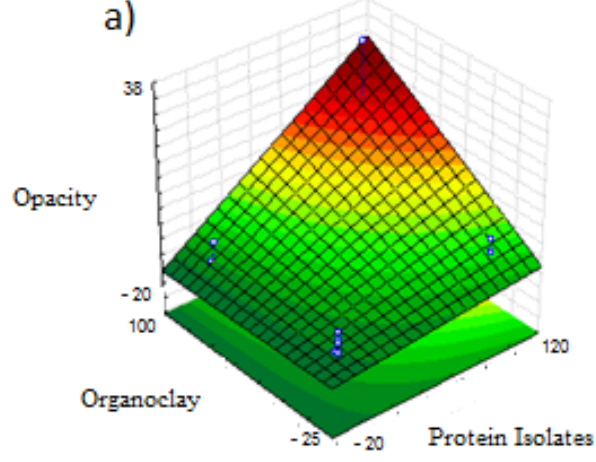

b)

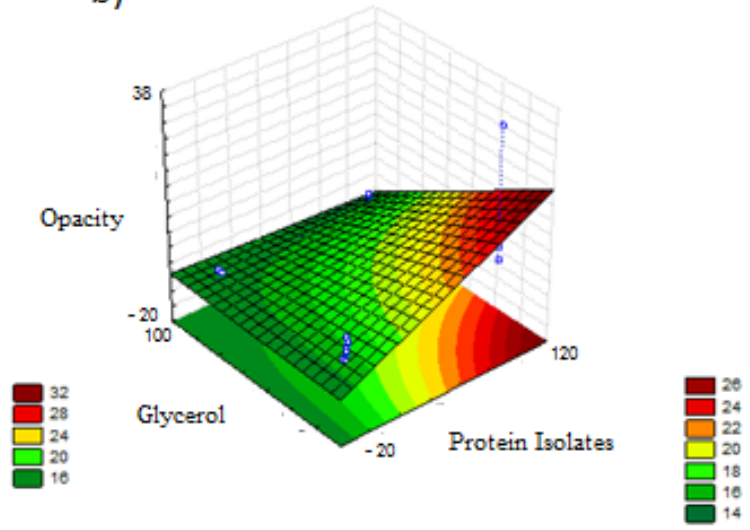

Figure 2. Response Surface of opacity as a function of the concentration of (a) protein isolate and MMT (b) protein isolate and glycerol. 


\subsubsection{Structural properties}

The film with the best formulation, determined from the experimental design, was characterized for its structural properties.

\subsubsection{Infrared spectroscopy (FTIR)}

Figures $4 \mathrm{a}$ and $4 \mathrm{~b}$ shows the infrared spectra of films without and with the addition of montmorillonite (MMT).

The spectra show an increase in the bands of $50 \mathrm{~cm}^{-1}$ with the incorporation of MMT, one can see the peaks in the same wavelength on both films, but the number of waves with MMT seems to be slightly lower due to enlargement in some cases, as is in the case of the $3000-3600 \mathrm{~cm}^{-1}$ region. This is possible due to the interaction of the chain of the film components with MMT through hydrogen bonds ${ }^{[18]}$.

Peaks around 2800 to $2900 \mathrm{~cm}^{-1}$ can be associated to asymmetric and symmetric stretching of the $\mathrm{C}-\mathrm{H}$ bonds (from $\mathrm{CH}_{3}$ and $\mathrm{CH}_{2}$ groups). It can be verified that they are expanded further in films with addition of montmorillonite, Santos ${ }^{[19]}$ studied the effects of various clays and found that they all had this functional group, because they presented peaks around this $2800 \mathrm{~cm}^{-1}$ band. In this study, the wider band shown approximately at the region of $2800 \mathrm{~cm}^{-1}$, in
Figure $4 b$, represents the functional group of montmorillonite nanoclay.

Figure $4 \mathrm{~b}$ shows bands in the $3600-3400 \mathrm{~cm}^{-1}$ region, corresponding to stretching vibration (axial) of the hydroxyl groups related to the water adsorbed between the MMT plates. The characteristic bands of Si-O-Si bonds were observed in the region between $1150-1020 \mathrm{~cm}^{-1}$ and in the range of $945-810 \mathrm{~cm}^{-1}$, corresponding to octahedral layers of the alumino silicate $\mathrm{Si}-\mathrm{O}-\mathrm{Al}^{[20]}$.

The peak located around $1000 \mathrm{~cm}^{-1}$ may be related to the interaction between the plasticizer (glycerol OH group), and the structure of the film ${ }^{[21]}$.

Therefore, by spectroscopic analysis, the main structural characteristics of the prepared films and the interactions between the protein isolate and montmorillonite could be observed. These results suggest that there was an interaction between CPI and MMT, the amplitudes of the peaks of MMT films were higher, although both films exhibit similar peaks.

\subsubsection{Scanning electron microscopy (SEM)}

Figures $5 \mathrm{a}$ and $5 \mathrm{~b}$ shows the scanning electron microscopy for the chicken protein isolate films with and without incorporation of montmorillonite, respectively,
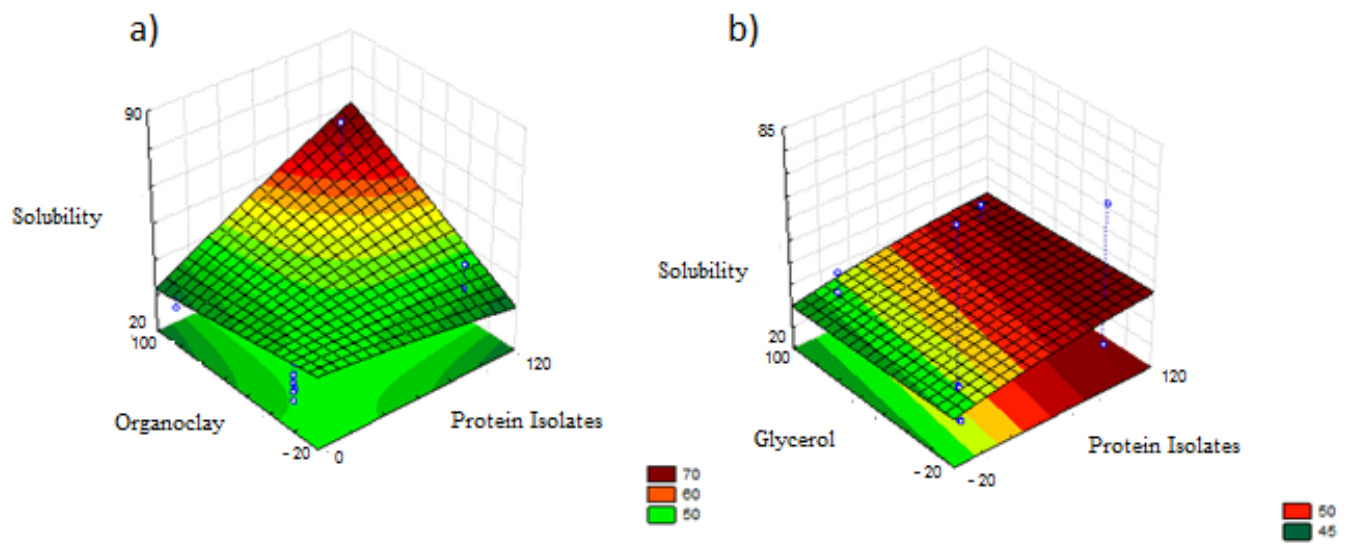

Figure 3. Response Surface of solubility as a function of the concentration of (a) protein isolate and MMT (b) protein isolate and glycerol.

(a)

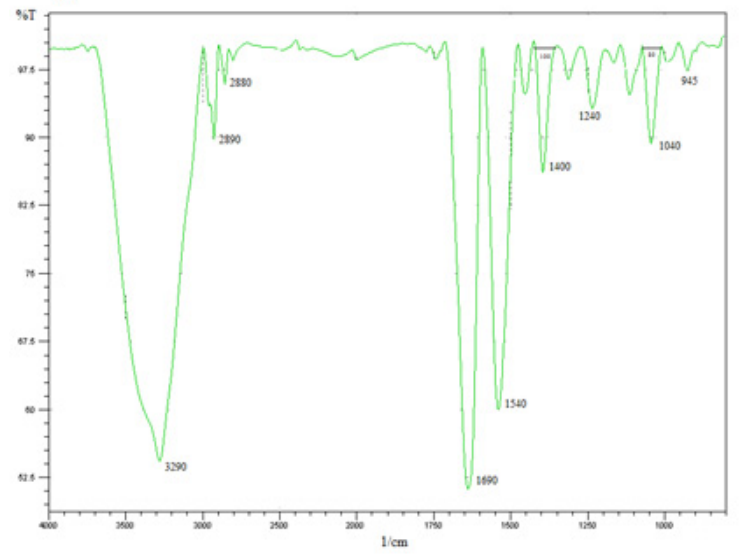

(b)

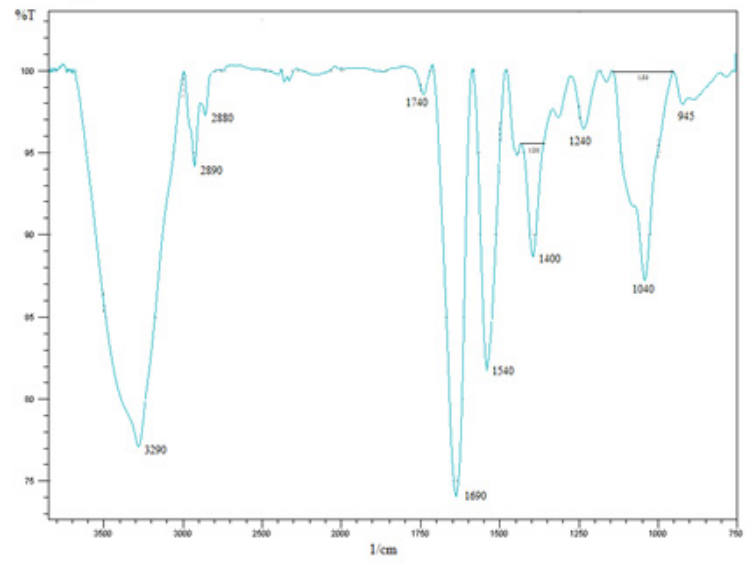

Figure 4. Infrared spectroscopy of CPI films (a) without the addition montmorillonite (b) with the addition montmorillonite. 
a)

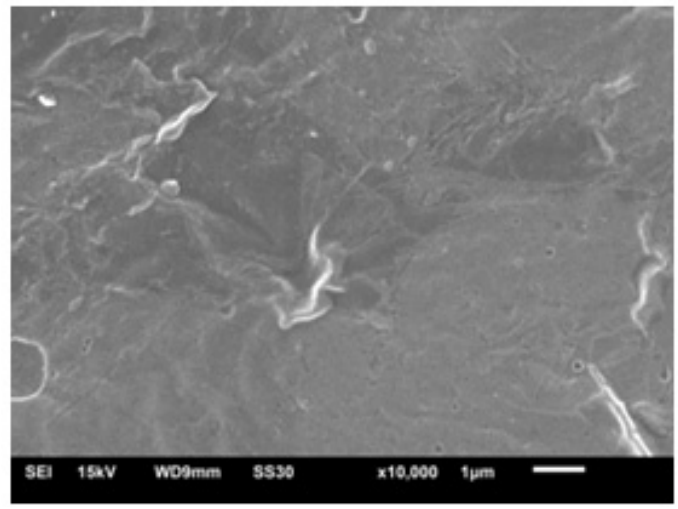

b)

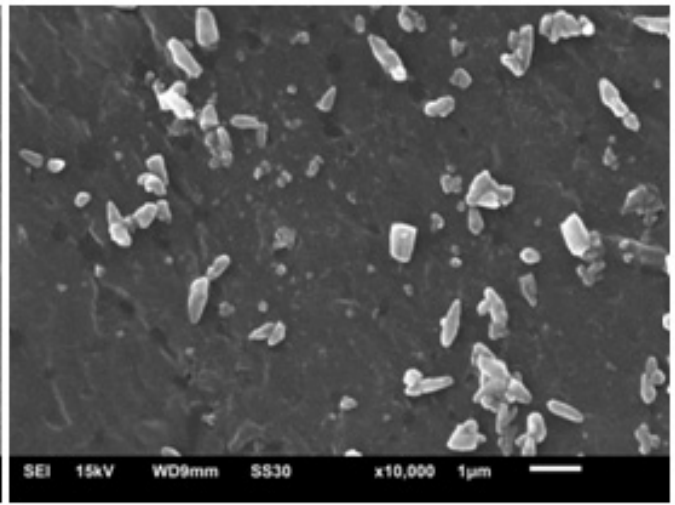

Figure 5. SEM of protein isolate films from mechanically deboned chicken meat (a) without the addition of montmorillonite (b) with the addition of montmorillonite.

while Figure 6 shows the microscopy of natural MMT ${ }^{[22]}$. Scanning electron microscopy can be used to evaluate the homogeneity of the films, the structure of the layer, pores, cracks and surface smoothness ${ }^{[23]}$.

In the scanning electron microscopy with a $10,000 \mathrm{x}$ magnification, shown in Figure 6, the difference in the morphology of the films can be seen. In Figure 5a, a compact and homogeneous structure was observed, showing the interaction of the protein with the plasticizer, unlike Figure $5 b$, which, in the presence of MMT, shows granules in their structure, representing clusters of MMT nanoclay.

Micrograph (Figure 7) shows non-uniform granule-shaped small particles well separated into different parts, however these are not presented in form of beads which is the natural form of MMT (Figure 6) ${ }^{[22]}$. These changes are directly related to interleaving and adsorption of the proteins and plasticizers with montmorillonite.

These discontinuities in the film structure can provide the formation of preferential pathways for diffusion of water vapor, which would explain the high water vapor permeability (WVP) of films Bodini, however in this case there was no effect of MMT on the WVP of the films ${ }^{[24]}$.

\subsubsection{X-Ray Diffraction (XRD)}

The XRD patterns of the protein isolate-based films from MDCM are shown in Figure 8. It can be seen that the spectra are different, suggesting the presence of distinct structures in the different layers of the film.

It can be noted that the nanocomposite film with the presence of MMT shows peaks, representing crystalline phases not presented in films without $\mathrm{MMT}^{[25]}$. This is due to the fact that when the radiation is incident on the surface layer of a film with MMT, it has an incident irradiation reflex, representing an amorphous film, probably due to its composition, this potential depends strongly on the substrate. In study analyzed XRD in thin chalcogenide films and found that the films are mostly amorphous, with oxidation evident $^{[26]}$. This oxidation is not advantageous, because if the film is oxidized, there is great chance of oxidizing the product packaged as well.

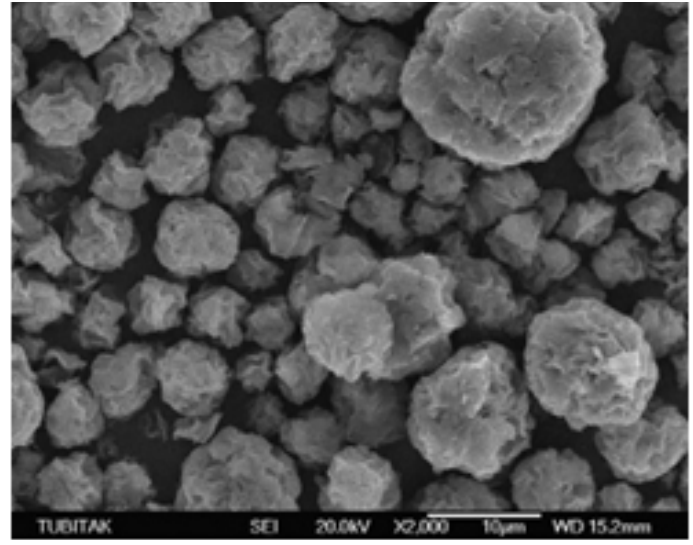

Figure 6. SEM of natural montmorillonite (MMT-Na), at a magnification of 2000x. Source: Sarier et al. ${ }^{[22]}$.

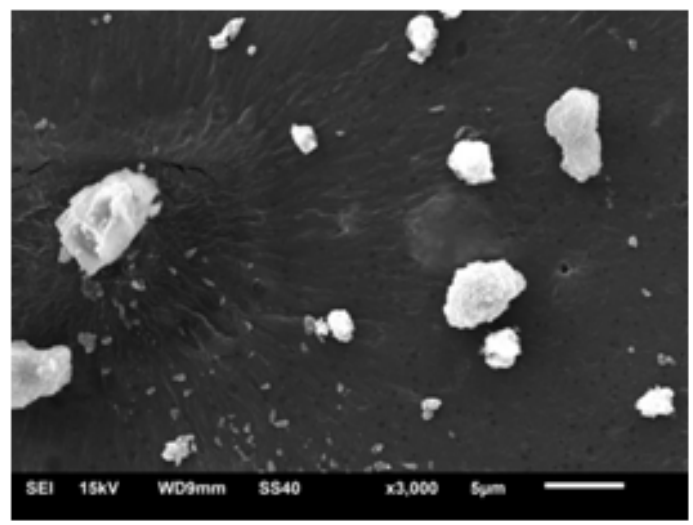

Figure 7. SEM of protein isolate films from mechanically deboned chicken meat with addition of montmorillonite at a 3000x magnification.

The small peak near $20^{\circ}$ in the active nanocomposite film with MMT is characteristic of the crystalline phase of polymers ${ }^{[27]}$. And the other peaks between 20 and $40^{\circ} ; 40^{\circ}$ and $60^{\circ}$ correspond to the reflection of mineral structures, and 


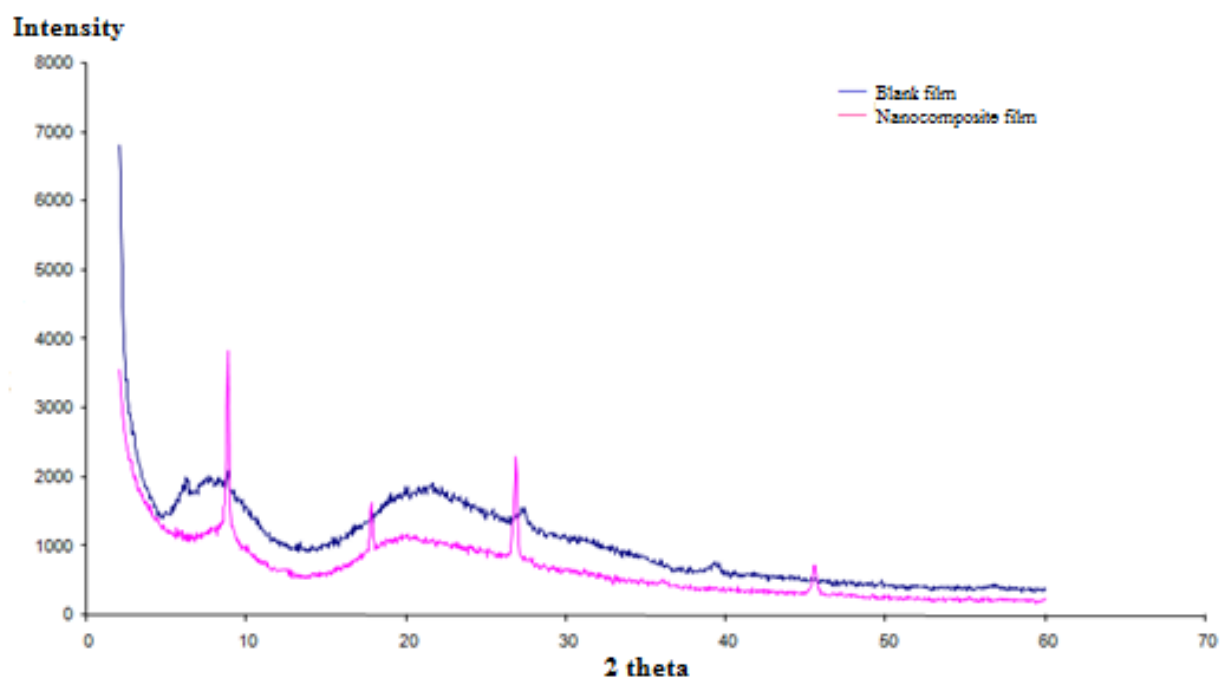

Figure 8. XRD of films of protein isolate from MDCM without montmorillonite (blank) and with montmorillonite (active film).

may be zinc or iron, which are more evident in nanocomposite films because of the composition of the montmorillonite ${ }^{[28]}$.

In their sample without MMT, obtained no peaks either, indicating that no crystalline structure was evident ${ }^{[18]}$.

\section{Conclusion}

It was possible to obtain nanocomposite films from chicken protein isolate added with montmorillonite. On assessing the structural properties (SEM, FTIR and XRD), interleaving between the isolate and montmorillonite can be noted.

It was found that the elongation to break and water vapor permeability of the films were not affected by variables in the experiment (chicken protein isolate; glycerol; montmorillonite), while the other properties were. The low solubility and opacity and high tensile strength of the films occurred at a high montmorillonite concentration $\left(0.8 \mathrm{~g} .100 \mathrm{~mL}^{-1}\right)$, low glycerol $\left(0.2\right.$ g. $\left.100 \mathrm{~mL}^{-1}\right)$, intermediate chicken protein isolate $\left(2 \mathrm{~g} .100 \mathrm{~mL}^{-1}\right)$ and a heat treatment of $70^{\circ} \mathrm{C}$.

\section{Acknowledgements}

The authors acknowledge the financial support by the National Council for Scientific and Technological Development $(\mathrm{CNPq})$ and the grant provided by the Coordination for the Improvement of Higher Education Personnel (CAPES) of Brazil.

\section{References}

1. Hua, Y., Huang, Y., Qiu, A., \&Liu, X. (2005). Properties of soy protein isolate prepared from aqueous alcohol washed soy flakes.Food Research International, 38(3), 273-279. http:// dx.doi.org/10.1016/j.foodres.2004.05.010.

2. Souza, C. O., Silva, L. T., \&Druzian, J. I. (2012). Comparative studies on the characterization of biodegradable cassava starch films containing mango and acerola pulps.Química Nova, 35(2), 262-267. http://dx.doi.org/10.1590/S0100-40422012000200006.
3. Quintero, E. S. M., \&Sobral, P. J.A. (2000). Preparo e caracterização de proteínas miofibrilares de tilápia-do-nilo para elaboração de biofilmes.Pesquisa Agropecuária Brasileira, 35(1), 179-189. http://dx.doi.org/10.1590/S0100-204X2000000100020.

4. Mali, S., Grossmann, M. V. E., \&Yamashita, F. (2010). Filmes de amido: produção, propriedades e potencial de utilização. Ciências Agrárias, 31, 137-156. Retrieved in 22 July 2015, from http://www.uel.br/revistas/uel/index.php/semagrarias/ article/view/4898/4363

5. Chivrac, F., Pollet, E., Dole, P., \&Avérous, L. (2010). Starch-based nano-biocomposites: plasticizer impact on the montmorillonite exfoliation process.Carbohydrate Polymers, 79(4), 941-947. http://dx.doi.org/10.1016/j.carbpol.2009.10.018.

6. Schlemmer, D., Angélica, R. M., Gomes, A. C. M. M., \&Sales, M. J. A. (2009). Morfologia de filmes de amido termoplástico e montmorilonita (TPS/MMT) usando óleos vegetais do cerrado como plastificantes. In Anais do $10^{\circ}$ Congresso Brasileiro de Polimeros (pp. 1-8). São Carlos: ABPol.

7. Souza, M. A., Pessan, L. A., \&Rodolfo, A., Jr.(2006). Nanocompósitos de poli (cloreto de vinila) (PVC) / Argilas organofílicas.Polímeros: Ciência e Tecnologia, 16(4), 257-262. Retrieved in 22 July 2015, from http://www.scielo.br/pdf/po/ v16n4/01.pdf

8. Ray, S. S., \&Okamoto, M. (2003). Polymer/layered silicate nanocomposites: a review from preparation to processing. Progress in Polymer Science, 28(11), 1539-1641. http://dx.doi. org/10.1016/j.progpolymsci.2003.08.002.

9. American Society for Testing and Materials-ASTM. (2001). E96-95: standard test methods for water vapor transmission of thin plastic sheeting. Philadelphia: ASTM.

10. American Society for Testing and Materials-ASTM. (1995). E96-95: standard test methods for water vapor transmission of thin plastic sheeting. Philadelphia: ASTM.

11. Fakhouri, F. M., Fontes, L. C. B., Gonçalves, P. V. M., Milanez, C. R., Steel, C. J., \&Collares-Queiroz, F. P. (2007). Films and edible coatings based on native starches and gelatin in the conservation and sensory acceptance of Crimson grapes. Ciência e Tecnologia de Alimentos, 27(2), 391-393. http:// dx.doi.org/10.1590/S0101-20612007000200027.

12. Brandelero, R. P. H., Grossmann, M. V., \&Yamashita, F. (2013). Hidrofilicidade de filmes de amido/poli (butileno 
adipato co-tereftalato) (Pbat) adicionados de tween 80 e óleo de soja.Polímeros: Ciência e Tecnologia, 23, 270-275. http:// dx.doi.org/10.4322/S0104-14282013005000011.

13. Cortez-Vega, W. R., Bagatini, D. C., Souza, J. T. A., \&Prentice, C. (2013). Nanocomposite biofilms obtained from Whitemouth croaker (Micropogonias furnieri) protein isolate and Monmorilonite: evaluation of the physical, mechanical and barrier properties.Brazilian Journal of Food Technology, 16(2), 90-98. http://dx.doi.org/10.1590/S1981-67232013005000011.

14. Rodrigues, M. I., \&Lemma, A. F. (2009). Planejamento de experimentos e otimização de processos. São Paulo: Cárita.

15. Zavareze, E. R., Halal, S. L. M., Telles, A. C., \&PrenticeHernández, C. (2012). Biodegradable films based on myofibrillar proteins of fish.Brazilian Journal of Food Technology, 4, 53-57. http://dx.doi.org/10.1590/S1981-67232012005000038.

16. Laohakunjit, N., \&Noomhorm, A. (2004). Effect of plasticizers on mechanical and barrier properties of rice starch film.Stärke, 56(8), 348-356. http://dx.doi.org/10.1002/star.200300249.

17. Nascimento, S. D., Oliveira, T. A., Santos, F. K. G., Aroucha, E. M. M., \&Leite, R. H. L. (2013). Effect of clay addition on the properties of chitosan biofilm.Revista Verde de Agroecologia e Desenvolvimento Sustentável, 8(1), 306-312. Retrieved in 22 July 2015, from http://www.researchgate.net/profile/ Suliene_Nascimento/publication/264274306_Efeito_da_ adio_de_argila_nas_propriedades_de_biofilme_de_quitosana/ links/5435a9a90cf2bf1f1f2b360e.pdf

18. Slavutsky, A. M., Bertuzzi, M. A., Armada, M., García, M. G., \&Ochoa, N. A. (2014). Preparation ans characterization of montmorillonite/brea gum nanocomposites films.Food Hydrocolloids, 35, 270-278. http://dx.doi.org/10.1016/j. foodhyd.2013.06.008.

19. Santos, S. M. (2011). Influência da adição de montmorilonita nas propriedades térmicas e mecânicas de nanocompósitos com matriz de epóxi (Master's dissertation). Instituto Alberto Luiz de Coimbra, Rio de Janeiro.

20. Delpech, M. C., Miranda, G. S., \&Santo, W. L. E. (2011). Dispersões aquosas a base de nanocompósitos de poliuteranos e argilas hidrofílicas brasileiras: síntese e caracterização. Polímeros: Ciência e Tecnologia, 21(4), 315-320. http://dx.doi. org/10.1590/S0104-14282011005000054.
21. Bergo, P., \&Sobral, P. J. A. (2007). Effects of plasticizer on physical properties of pig skin gelatin films.Food Hydrocolloids, 21(8), 1285-1289. http://dx.doi.org/10.1016/j.foodhyd.2006.09.014.

22. Sarier, N., Onder, E., \&Ersoy, S. (2010). The modification of Na-montmorillonite by salts of fatty acids: An easy intercalation process.Colloids and Surfaces: Physico Chemical and Engineering Aspects, 371(1-3), 40-49. http://dx.doi. org/10.1016/j.colsurfa.2010.08.061.

23. Bilbao-Sainz, C., Avena-Bustillos, R. J., Wood, D. F., Williams, T. G., \&Mchugh, T. H. (2010). Nanoemulsions prepared by a low-energy emulsification method applied to edible films. Journal of Agricultural and Food Chemistry, 58(22), 1193211938. PMid:20977191.http://dx.doi.org/10.1021/jf102341r.

24. Bodini, R. B. (2011). Desenvolvimento de materiais poliméricos bioativos à base de gelatina e própolis (Master's dissertation). Faculdade de Zootecnia e Engenharia de Alimentos, Universidade de São Paulo, Pirassununga.

25. Jesus, F. A. A., \&Macedo, Z. S. (2010). Síntese de filmes finos de germanato de bismuto.Scientia Plena, 6(3), 1-6. Retrieved in 22 July 2015, from http://www.scientiaplena.org.br/sp/article/ view/257/49

26. Moura, P. R., Almeida, D. P., Lima, J. C., Ponciano, C. R., \&Campos, C. E. M. (2009). Propriedades estruturais de ligas e filmes finos calcogênicos submetidos à luz síncrotron.Revista Brasileira de Aplicações de Vácuo, 28, 1-6. http://dx.doi. org/10.17563/rbav.v28i1-2.481.

27. Pattabi, M.,Amma, B. S., \&Manzoor, K. (2007). Photoluminescence study of PVP capped CdS nanoparticles embedded in PVA matrix.Materials Research Bulletin, 42(5), 28-35. http://dx.doi. org/10.1016/j.materresbull.2006.08.029.

28. Fernandes, D. M., Silva, R., Hechenleitner, A. A. W., Radovanovic, E., Melo, M. A. C., \&Pineda, E. A. G. (2009). Synthesis and characterization of $\mathrm{ZnO}, \mathrm{CuO}$ and mixed $\mathrm{Zn}$ and $\mathrm{Cu}$ oxide.Materials Research Bulletin, 115(1), 5-10. http:// dx.doi.org/10.1016/j.matchemphys.2008.11.038.

Received: July 22, 2015

Revised: May 23, 2016

Accepted: June 03, 2016 